Journal Plus Education, ISSN: 1842-077X, E-ISSN (online) 2068-1151 Vol XIX (2018), No. 1. pp. 225-237

\title{
THE INFLUENCE OF REWARDS USED IN CHILD EDUCATION OVER THE DEVELOPMENT OF THEIR PERSONALITY
}

\author{
Maria LUNGU, Ph.D., \\ West University of Timişoara \\ maria.lungu@yahoo.com
}

\begin{abstract}
Rewards are used as methods of educating pupils / children in the educational system, in school and in the family. Their role is to encourage, enforce, stimulate and confirm the accepted behaviour in the social and cultural environment in which the pupil / child is activating. Reward is actually a compensation for a positive action or activity, for a desirable behaviour. It can be of a material or emotional nature. We reward somebody in order to determine him to continue to be good, to repeat a certain behaviour or action because they help him progress and develop from a personal and professional point of view. The research regarding the reward system was done together with the students from West University of Timisoara. Its purpose was to emphasise the way in which rewards influence the development of one's personality.
\end{abstract}

Key words: rewards; praise; pupils/children; school; family;

\section{Introduction}

Rewards started to be used generously in the educational system once the behaviourist thinking system was introduced. J. B. Watson is considered the father of behaviourist although this current was put in place by E. L. Thorndike (learning by trial and error / trial and success, reward / punishment, the law of result) and I. P. Pavlov (classical conditioning conditioning before the behaviour). The most influential supporter of this thinking system was B. F. Skinner (operant / instrumental conditioning - the accent is put on conditioning the behaviour) who, by using the research tool called "Skinner's box", tried to prove that behaviour is operant. 
The basic concepts that Skinner operated with were positive reinforcement, negative reinforcementand punishment. "Positive reinforcement builds behaviour" according to Skinner (1971:160). Positive reinforcement considers that a behaviour that is stimulated in a desirable way or if it is rewarded there are great chances that it will be repeated or that it will be manifested in similar situations. Behaviour can be modified, modelled, "trained" by means of various reinforcement patterns from the external environment. This whole process is called operant conditioning. An operant represents any kind of behaviour that when it acts upon an environment it also produces consequences on it.

Operant conditioning refers to modelling or increasing the action frequency of behaviour, according to a predetermined model, strengthening or rewarding desirable behaviour when it is manifested. During conditioning expectancy appears, beliefs are developed and conviction that something is going to happen appears. If we consider classical conditioning the belief that certain stimuli will be followed by other stimuli appears (when turning on the light food appears) or, if we consider operant behaviour, that certain behaviours will generate certain results. Behaviourists have experimented with animal behaviour: dogs, cats, rats, pigeons etc.

Also, according to the theory of self-worth, people choose to become conformists or deviants depending on what will increase their respect and self-worth. For most people self-worth is generated and maintained by conforming to group expectancy of belonging or of reference. We can include here parents, teachers, relatives, friends, the group, the community we belong to. Conforming to group expectancy will be rewarded in a formal or informal way. People who are not rewarded at home or in school consider they "are not seen" or "are not heard" (Agabrian 2003:193).

On the other hand, according to Travis Hirschi's control theory (1969) each of us has various motives to become deviant, because each of us wants more than one can get. Despite this, most people conform! What determines this behaviour? According to Hirschi, most people are conformists because of their duties, responsibilities to their peers and their strong ties to the conventional society, whether it is parents, school, church, friends or community. Responsibilities and social duties are the ones that reward people for their social behaviour (Agabrian 2003:193 ).

In his books Alfie Kohn brings various arguments based on scientific studies against rewards. "Rewards punish (...) and exercise just as much control as punishments, even if they operate by seduction" (2014:53). Alfie Kohn considers that a reward is "an object or a wanted event which is conditioned by the fulfilment of certain criteria: if you do this you will get this" (2014:54). 
Journal Plus Education, ISSN: 1842-077X, E-ISSN (online) 2068-1151 Vol XIX (2018), No. 1. pp. 225-237

\section{Methodology}

The research was done during January-June 2017 period. The test sample was made up of 50 students from almost all faculties and from years I, II, III and Master's degree from West University of Timisoara. The research method was of qualitative nature - the partly structured interview, with the following key questions: if they have been rewarded what sort of method was used; what did it mean for them; who rewarded them (the family, school); in what situation was the reward used; how often have they been rewarded; how did they feel, what have they thought when they were rewarded; did they recognize their reward; was their personality influenced by the reward etc.

\section{Research objectives:}

6. Defining the concept of reward;

7. Identifying the causes that generate the use of reward in the education of the child / pupil;

8. Identifying the compensation methods used in the educational system;

9. Analysing the ways in which the rewards influence personality development;

10. Alternate methods to reward.

\section{Research hypothesis}

The more often children are rewarded the more conformist and dependent on other people's opinions they become.

\section{Results}

\section{F.P.}

"I was often praised. Sometimes I did not even deserve the praise, but because I was labelled as a good student, tenacious and intelligent, I always got the praise. I got diplomas, honours and awards in the Olympic competitions; I got gold and silver medals and trophies in sports competitions; I got very good marks in school - sometimes I did not deserve the best mark, but again my label as a good student helped. But maybe I am wrong in this respect. I got gifts from teachers - motivational letters, books, bookmarks and flowers. As a child I was "bribed" with sweets and toys to go to the doctor. My mother always wanted to reward my studying effort with a 
gift at the end of the semester (clothes, books, trips, a phone). Sometimes I would have been delighted to have some of her attention and time to tell her about a day in my life, all the good moments or the unrest I was facing."

\section{C.F.}

"I was rewarded with prises in competitions and the Olympics. It is wrong in a way that at a very young age we are inoculated with the idea of competition and the sometimes exaggerated wish to be the best. Especially in the Olympic contests the judges were not always fair. Many times, as a student, I was disappointed by such things and I was much more discouraged than motivated."

\section{B.A.}

"My relationship with my parents was mostly based on communication and open discussions and less on the idea that "if you do this, you will get something" and the other way around. It happened to me to be punished and rewarded as well, but there was nothing special about it. I did not have any punishments that I did not understand or successes that I felt went unnoticed. In school my rewards were mainly grades, awards or diplomas. Although I was happy about them, I came to realise that the opinion of the right people and self-evaluation were more important. There are two prises or rewards that have marked me, but not because of their importance, but because of the context and the people there. When I was in the $3^{\text {rd }}$ grade I wrote a composition about spring for the Romanian language class and after reading it, the teacher decided that it should be published in the school paper. In my mind, the school paper was for older students, privileged and good at everything they did. The fact that my composition was good enough for the school paper was more important to me than any mark. What I thought was important was the fact that the teacher did not make any remarks such as "it is the best composition", did not mark it, did not compare it with anything, but just took it as it was. In the $10^{\text {th }}$ grade I got my first prise while studying with my new musical instrument teacher - and I got the feeling that after a year I finally managed to make her proud. But because I do not see good or bad marks as being absolute, then I tend to treat them as common consequences of my actions." 
Journal Plus Education, ISSN: 1842-077X, E-ISSN (online) 2068-1151 Vol XIX (2018), No. 1. pp. 225-237

\section{O. N.}

"Marks - I was always happy when I got good results up until the $9^{\text {th }}$ grade - this was my way of asserting myself. Money - at some point my uncles would reward me with money for good marks, but I was not motivated by this. Fun - while in high-school, if I did my homework in school I was allowed to go out. When I finished high-school I was congratulated by my Maths and Romanian language teachers which made me feel extraordinary. I felt that my family was pleased with me as well. All this made me feel very good and content with myself."

\section{S.N.}

"Rewards - During my primary school my rewards was sweets or my mother would cook for me my favourite food or take me to McDonald's. During $5^{\text {th }}$ to $8^{\text {th }}$ grade my rewards were clothes and books. I became passionate about reading and I was not studying for rewards anymore, but because I wanted to prove to myself and to others that I was the best! In school, during $9^{\text {th }}$ to $12^{\text {th }}$ grade I got a lot of diplomas. I have a bunch of them at home. That is how I perceived success, through diplomas. Because I wanted to be the best and to be respected I worked for diplomas and good marks, although what I should have been interested in was the information in itself."

\section{U.R.}

"When I was in high-school, but also in primary classes it happened to me a lot to receive rewards for my interest in learning. The marks, diplomas and awards that I got were proof to me that I was able to study and they brought me a lot of satisfaction."

\section{N.D.}

"Praise - from my grandparents, my dad. When I managed to do something and when I got good grades I felt I was appreciated and I always wanted to succeed in my tasks; Appreciation - from my dad. In every situation I felt I was important to him, even when I did not perform at my best. He always found something to appreciate and this gave me courage to continue. Encouragement - from my dad. Even when I got a bad mark in Maths, he saw that I was trying hard and he would encourage me and because of his encouragement I managed to get over a lot of things in school. I owe my love for Maths to him and the fact that I study at a university in the same field." 
Journal Plus Education, ISSN: 1842-077X, E-ISSN (online) 2068-1151 Vol XIX (2018), No. 1. pp. 225-237

\section{G. H.}

"Teachers always praised me, appreciated me and offered me small gifts (books) in order to encourage me to keep learning just as well. For me these things did not have any special value. I was happy for some time, but they reminded me how little I knew and how slow I was progressing. My parents never rewarded me. Their appreciation for me was always spoken. They always told me: "I don't even expect anything else from you. You are good!" In my soul the only rewards that make me happy come from God. I call them blessings. My health, my money, my family, friends, everything I have I get them from His hands."

\section{K.M.}

"During secondary school, in classes V-VIII, I always had highest marks even when I deserved a lower mark teachers would forgive me. I participated in all sorts of contests and Olympics, I got diplomas, prizes and honourable mentions. In high school I won awards in contests and English Olympics. My colleagues listened to my opinion, I was trusted; I remember the contentment and pride of my parents and relatives. On the inside I felt a somewhat selfish pride in being the first in my class. I have proved to myself what I can do and my teachers and parents trusted me."

\section{F.M.}

"For me the biggest reward was my parents' contentment. I also got rewarded with diplomas from various contests and Olympics and with special results (such as at the Baccalaureate)."

\section{A.N.}

Toys from my parents if I was a good kid. It made me really happy, I felt rewarded for my efforts. My grandparents in the country offered me money for my birthday every time I visited. These rewards made me feel loved because it was not something I had to work for, but they also made me consider that I deserved more than I got. My parents gave me money as a reward for various house activities (vacuuming, washing the dishes). These rewards made me feel good because I felt that I have worked for the money. This is how I started to learn that money imply work and I should be more careful with it. I got praises from my relatives for my school results or 
Journal Plus Education, ISSN: 1842-077X, E-ISSN (online) 2068-1151 Vol XIX (2018), No. 1. pp. 225-237

contest results and they made me feel appreciated. Marks were the main rewards for which I have studied and I have done my duty. Good marks made me have a good opinion of myself and have influenced me in a positive manner and motivated me. The diplomas from year's end or from the Olympic contests made me feel that my work was worth something and that my results were appreciated. If I managed to do something special or respond in a different way from my colleagues I was praised in front of the class. This kind of rewards made me feel appreciated but also a little ashamed of my colleagues because I did not want to be perceived as arrogant."

\section{C.V.}

"If I try to think about it I can hardly remember some situations when I was rewarded for a good deed. My parents taught me that for good deeds I should not expect a reward because this is normal behaviour and I should not do something expecting something in return at the end. I was taught that if I do not behave I will be punished. I guess the lack of punishments was some sort of reward for my good deeds. The rewards I got in school were usually verbal encouragements from teachers. They had an effect upon me because they made me feel proud and confident."

\section{P.L.}

"I was nit rewarded for good marks in school or for normal behaviour. The most influential rewards were the verbal encouragements I received from my parents for helping them. Summer camp was a reward. The most important reward for my efforts in school was recognition of my good behaviour and good results in front of the class."

\section{T.I.}

"Material rewards have been an incentive for me to accomplish something because I have been spoiled as a kid and I got everything I wanted. This did not help me too much because I am dependent on my parents and I am afraid to leave the nest. I like to hear praises addressed at me. Most of the time they are my favourite rewards because they are rarely objective. Anyway, soulful rewards are the most important. I think that if I can't do a job properly it's better to not do it at all. When I managed to do something and I was praised they made me feel really confident." 
Journal Plus Education, ISSN: 1842-077X, E-ISSN (online) 2068-1151 Vol XIX (2018), No. 1. pp. 225-237

\section{A.B.}

"The long awaited volleyball I got from my mom - for winning a juniors' championship. All the girls in the team wanted that ball so I was very glad I got it and I wanted even better results. Praises from the maths teacher because I got the highest mark at the baccalaureate. I felt proud and content with my work and it made me want even better results."

\section{D.J.}

"When I got first place in a dancing contest my mother got me a laptop. I was very happy because I wanted it very much and she kept her word. When I started dancing I got the moves right from the start - the moves that the others have known for a very long time. The teacher praised me in front of my parents and dance colleagues. I was very proud of myself and I worked a lot, especially so that I could show them that the teacher was right. When I got the Baccalaureate my mother let me go to the seaside alone with my girlfriends. I was very happy that I managed to make my mother happy."

\section{R.A.}

"Talking about rewards, my parents have insisted on immaterial rewards (praise, appreciation etc.). I was rewarded for doing the right thing and for getting diplomas in school. They made me feel good, appreciated and understood. It influenced me in a positive way and helped me progress and try to be on my best behaviour. As a reward in school I got prizes for good results every year and for school Olympics contests. They made me feel like a winner, I felt they demonstrated my ambition and capacity to fight for what I wanted. I was very happy for the diplomas and the books I got because I felt I have worked hard for them and I deserved them. They have influenced me in a positive way and determined me to fight for a prize but on the other hand sometimes I feel I have focused too much on diplomas and less on school and extra-curricular activities."

\section{N.S.}

"My parents rewarded me for the high marks or for good deeds with gifts, sweets or praises. Rewards have helped me grow, be more responsible, show respect and understand that by working I can get anything. In school rewards were high marks that I got and that transformed me in a competitive person. Praises from teachers made me feel important and the fact that they 
called me smart, quick learning and with high objectives made me feel proud of my qualities and determined me to be better."

\section{A.W.}

"Appreciations in the form of praises or hugs have constantly been present in the success moments for which I have worked hard. Although these have made me feel appreciated and confident in myself I have noticed that in time the effect was almost reversed. I have become so convinced that every time I was faced with problems I will manage that when I happened to fail I was affected from a mental point of view. Noticing what was happening, my mother changed her tactic and decided to reward me for greater efforts. This way usual appreciations have turned into rarer ones, associated with external stimuli. For example, in school years and especially during puberty I was offered a gift for high marks at the end of every class. I felt much more motivated to work and final recognition brought me a lot of satisfaction. This change affected my perception of myself. I learned that it is normal to have limits and have failures but what matters is to win the final battle."

\section{A.A.}

"There were no rewards in our family. It was something normal to learn and be a good child. I was always among the first and I did not make problems for my parents. The gifts I received from them have never been as a reward for good deeds. In school I have received a lot of praise for my high marks. I have taken part in contests and Olympics where I successfully represented our school. Every mark and every appreciative word from the teachers made me work even harder in order not to disappoint them. Because I was always among the first in results in time I started to react inappropriately to critics. During high school my mother has realised this. I was attending private tutoring in order to get prepared for faculty. The teacher I had was very severe and kept criticising me. I was discouraged and started to get low marks. I simply stopped learning! Then suddenly he started to encourage me and even praise me. As a result I started to learn and get good grades. Years later I found out that his change in behaviour was determined by my mother - she talked to him and explained that if he was not encouraging he was blocking my learning." 
Journal Plus Education, ISSN: 1842-077X, E-ISSN (online) 2068-1151 Vol XIX (2018), No. 1. pp. 225-237

\section{H.B.}

"I was a model pupil in school and I learned all the time and had good grades. I had the best performance in school and I was passionate about drawing. I had a lot of rewards throughout the years: high grades, teachers' respect, admiration from my colleagues and a new social standing in school. Everybody was counting on me, starting with my colleagues who were asking me to help them with their homework and tests, and ending with my teachers who praised me and respected me. But there was also the physics teacher who was always testing my patience and my memory in front of the class. I felt a huge responsibility on my shoulders and it made me feel it more like a punishment than a reward. Out of the blue someone asked me to help and I could not refuse. I cannot say I did not like the feeling back then. But trying to help others I was wearing myself out! In time I realized that my friends were just driven by interest."

\section{V.V.}

"The most used rewards in my family were praise and encouragement. I have learned to cook by talking on the phone with my mother. She explained what I had to do and she encouraged me. It was really important for me to know that she supported me and that she would not scold me if I made a mistake. In school I have had my share of rewards, such as praise and encouragement. This has always motivated me to learn and get good marks."

\section{J. N.}

"Mostly the rewards in school have been expressed through marks, which have stimulated my desire for self-perfection and recognition in front of the others. The good marks I got made me feel relieved because the things I have done did not go unnoticed. At the same time a huge reward in school was my teachers' recognition. They have compensated their behaviour in primary classes with the nice words and praises. Also, the only material compensation that I got from my family was at the graduation from secondary school when my parents sent me for the first time on a trip abroad. In the family the main rewards were recognition, affection and trust. Thus, when I was successful and I did a good job, the trust my parents had in me grew up to the point when they allowed me to do what I wanted because I had their credit." 
We can see from the above interviews that most rewards have to do with activity and performance in school. The rewards of the interviewed people have been firstly as good marks, prizes, diplomas and as a consequence the rewards in the family followed, like money and small gifts - mobile phones, clothes, trips, laptops etc. We can see that for some of them praise is a very important form of appreciation for their work. The biggest fear was not to disappoint their teachers and parents. A very important reward was making their parents happy, and especially the mother. One of the interviewed persons mentions that the reward proves you can get anything you want as long as you work hard and it makes you more ambitious, but she admits that wanting so much to get compensated is not in the best interest of intrinsic motivation. They want to be praised because this confirms them that what they do is alright. They need to be appreciated and respected, they need support and encouragement because this is what makes them go on, as they say in the interviews.

\section{Conclusions}

I think that before we become "examples" in distributing rewards and praises in children's education we should first ask ourselves what kind of adults we want to educate. What kind of educational results do we want? Do we want to form some obedient, humble, subservient person, dependent on the approval and appreciation of others or do we want autonomous, independent, responsible people with a good image and positive self-esteem?

Rewards have a precise purpose and they focus on extrinsic motivation: if you do this, then you get this! The use of rewards may not be beneficial to children, in the idea that they will end up doing certain things, taking on certain activities, engaging in certain relations only if they get something in return. Otherwise they will become unattractive, worthless and they will have no interest in engaging in certain tasks or getting involved in certain relations. The absence of reward will make them lose motivation and give up on a task or a relationship.

The frequent use of rewards will diminish significantly the intrinsic sense of responsibility, judging everything through the win-lose filter. When they do not get something in return they lack the motivation to do a certain thing. Also, as children grow up, they will lose the interest in certain actions if the rewards are not multiplied or are not more stimulating.

In conclusion, we will be forced to use even more rewards, to praise as much as possible, if we want to keep motivation running for the children and get them to accomplish what we want.

Rewards represent a positive conditioning of children's behaviour to the standards imposed by the parents and teachers. Praise and reward is the 
way that adults control and manipulate the behaviours and thinking of children.

The focus is on control and not on the relation! This is a vertical relation, one of power between the child and parent / teacher: "I know what is better for you". Through the standards imposed by parents and teachers, the child will always feel judged and evaluated and will make all the efforts to impress his teachers and parents, to make them happy and to receive the praise, appreciation and approval from them.

This way we create for them behaviours dependent on approvals, appreciations and recognition of others. This way we "help" the children become dependent on high marks, awards, diplomas, certain people, social status etc. Their esteem and self-image will be regulated just according to what others are saying and thinking about them.

Children will do certain activities not for themselves and their own joy or contentment, but in order to please others. They will become dependent on the opinions of parents and teachers, they will find it very hard to take decisions on their own, because their self-esteem will be affected.

In the case of a failure (low grades, not passing an exam, losing a contest, failing a relationship etc.) they will lack motivation, will be demoralized, depressed, will lose their interest in studying. By rewarding them the focus is put on what the children do and not on what they are and what they feel!

It is already known that children have an intrinsic need to explore, to experiment, to know a lot of things and to learn what is new. This need becomes blocked and suffocated by the system of rewards used at home and in school.

Also, praise makes children dependent on the person that is praising them and generates the belief that "justifies" the preoccupation for reward. It focuses on the result and not the effort! Those who become dependent on praise do not get engaged in a task unless they "get something" or they are "seen or heard" by somebody.

We need to develop intrinsic motivation in children - it is the fire that needs to keep on burning! Children need to be supported and helped to understand that not everything they need to do will be easy, but that with effort and perseverance it will not be impossible, and effort is needed in any activity or action.

Also, educators must take into account the needs of the children (to be respected, heard, seen, understood etc.), their capacities, abilities and resources and the need to be offered an alternative, to be encouraged to find a solution, to cultivate their empathy, patience, generosity etc.

It is very important in the educational process that we focus on encouragement - it helps in the development of intrinsic motivation. 
Encouragement focuses on the learning process and not on the result or performance. Encouragement underlines the effort and it represents a continuous self-evaluation - what was or was not good, where he must work some more, what he must do in order to evolve, how did he feel during the learning process etc.

This thing helps children break free from the way in which they are approved or appreciated by others. "Children must be able to operate corrections and adjustments based on their own evaluations." (Faber 2008:168). In this case children do not feel let down if they are not validated by others.

I think it is very important to develop in children the intrinsic joy of their own actions or relations. They must be helped to focus on the contentment and fulfilment that come from their own activities or relations and to understand what their proper finality is.

I consider that only by accessing their intrinsic motivation children will be able to mobilize their entire resources in order to reach their full potential and this way they will become healthy adults form an emotional, social and physical point of view.

\section{References:}

Agabrian, M. (2003). Sociologie generală. Iaşi: Institutul European.

Faber, A. (2008). Comunicarea eficientă cu copiii acasă şi la şcoală, Bucureşti Editura Curtea Veche.

Kohn, A. (2013). Parenting necondiţionat - de la recompense şi pedepse la iubire şi inţelegere, Bucureşti:Editura Media Est Publishing.

Kohn, A. (2014). Pedepsiţi prin recompense, Bucureşti: Editura Media Est Publishing.

Kohn, A. (2014). Mitul copilului răsfăţat, Bucureşti: Editura Herald.

Kohn, A. (2015). Mitul temei pentru acasă, București: Editura Herald.

Skinner, B.F. (1971). Revoluţia ştiinţifică a invăţământului, Bucureşti:

Editura Didactică şi Pedagogică.

Thornidike, E.L. (1983). Învăţarea umană, Bucureşti: Editura Didactică şi Pedagogică. 